\title{
O JORNALISTA RUBEM BRAGA: ANIMAL POLÍTICO, CORRESPONDENTE DE GUERRA
}

\author{
Daniel Zanella ${ }^{1}$ \\ Elza Aparecida de Oliveira Filha ${ }^{2}$
}

\section{Resumo}

Em mais de 60 anos de carreira, Rubem Braga redigiu aproximadamente 15 mil crônicas, parcialmente reunidas em diversas coletâneas e antologias. O presente artigo apresenta dois recortes específicos de sua vasta obra, entendendo que, apesar das idiossincrasias próprias da literatura e do jornalismo, estes são dois universos que se comunicam e, no caso específico de Braga, coexistem intensamente em um mesmo indivíduo, acima de tudo, e ao seu modo, jornalista. A partir da escolha de textos com visível poder informativo - capazes de elucidar as raízes conjuntas entre a crônica e o jornalismo e contribuírem para um melhor entendimento de Rubem Braga e seu valor jornalístico - o artigo trabalha com as facetas: Rubem Braga: Político, em que se analisa o seu envolvimento em alguns momentos históricos do país e as suas posições ideológicas como cronista e jornalista que presenciou os fatos, e Rubem Braga: Correspondente de Guerra, importante momento em que o autor cobre a Segunda Guerra Mundial.

Palavras-chave: Jornalismo, crônica, Rubem Braga.

\begin{abstract}
Rubem Braga worked more than 60 years as a journalist. Along this period, he wrote approximately 15000 articles, partially assembled on various compilations and anthologies. This article presents two specific clippings of his vast work, understanding that, despite the differences between literature and journalism, those two universes are linked and, in the specific case of Braga, intensely coexist. We choose texts with visible informative power - able to elucidate the joint root between chronicle and journalism and to contribute to a better understanding of Rubem Braga and its journalistic importance. The aim of this article is to show two aspects of the author: first, Rubem Braga and politics, where it is analyzed his involvement in some political situations and his ideological positions as a columnist and journalist who witnessed the facts; second, Rubem Braga, the war correspondent, where we analyze his work as a chronicler during the Second World War.
\end{abstract}

Keywords: Journalism, chronicle, Rubem Braga.

\section{O jornalismo e a crônica}

Nascido em Cachoeiro do Itapemirim, Espírito Santo, em 12 de janeiro de 1913, Rubem Braga narrou importantes momentos históricos, como a Revolução de 30, o Estado Novo, o nazismo, a atuação dos pracinhas da FEB, o suicídio de Getúlio Vargas, o franquismo, o salazarismo, a revolução cubana, o Golpe de 64 e a mão de ferro da ditadura.

Sua trajetória no jornalismo é rica e precoce. Logo aos 14 anos incompletos, publica pela primeira vez, em um periódico chamado $O$ Itapemirim, órgão oficial do Grêmio Domingos Martins, do Colégio Pedro Palácios. O texto, um tanto eloquente nos adjetivos, é

\footnotetext{
${ }^{1}$ Aluno do curso de Jornalismo da Universidade Positivo.

${ }^{2}$ Jornalista (UFPR), mestre em Sociologia (UFPR), doutora em Comunicação (Unisinos), professor do curso de Jornalismo da Universidade Positivo.
} 
resultado de uma atividade realizada na disciplina de Língua Portuguesa sobre a "reveladora indiscreta, a tradutora inconsciente dos segredos d'alma": a lágrima. Ingressou oficialmente na imprensa, sem remuneração, aos 15 anos, em um impresso familiar chamado Correio do Sul, lançado em 30 de junho de 1928 por seus irmãos Armando de Carvalho Braga e Jerônimo Braga.

Rubem Braga é um autor fundamental no entendimento da literatura e do jornalismo brasileiro. Foi um profissional concebido no impresso, capaz de permanecer em meio ao diário noticioso efêmero e caso singular de escritor a desenvolver carreira sólida exclusivamente na crônica. A crônica, estilo amplamente adotado por Braga em sua fecunda carreira, é uma espécie de anfíbio de difícil definição. Sua origem - a palavra é trazida de Khronos, deus grego personificado do tempo - remonta às trocas narrativas mais antigas das civilizações, antes mesmo da escrita.

\begin{abstract}
A experiência transmitida oralmente é a fonte de que hauriram todos os narradores. E, entre os que transcreveram as estórias, sobressaem aqueles cuja transcrição pouco se destaca dos relatos orais dos muitos narradores desconhecidos. [...] A narrativa, tal como se desenvolve durante muito tempo no círculo dos ofícios mais diversos - do agrícola, marítimo e, depois, do urbano -, é, por assim dizer, uma forma artesanal da comunicação. Sua intenção primeira não é transmitir a substância pura do conteúdo, como o faz uma informação ou uma notícia. Pelo contrário, imerge essa substância na vida do narrador para, em seguida, retirá-la dele próprio. Assim a narrativa revelará sempre a marca do narrador (BENJAMIN, 1975, p.64).
\end{abstract}

A terminologia é emprestada da relação intrínseca que o gênero tinha (e ainda mantém) com o tempo cronológico, sequencial, aquilo que pode ser medido, ou em um momento indeterminado, onde alguma coisa importante aconteceu e precisou ser relatada (SOUZA, 2012). A forma como conhecemos a crônica hoje - diferenciada principalmente no Brasil, onde, nos jornais, ganhou musculatura própria - paga tributo aos oradores clássicos.

Os primeiros textos históricos são justamente as narrações de acontecimentos, feitas por ordem cronológica, desde Heródoto e César a Zurara e Caminha. A atividade dos cronistas vai estabelecer a fronteira entre a Logografia - registro de fatos, mesclado com lendas e mitos - e a história narrativa - descrição de ocorrências extraordinárias baseadas nos princípios da verificação e da fidelidade (MELO, 2003, p.139).

A rota percorrida pela crônica incide anteriormente nos ideais de literatura e jornalismo, fortalecidos na Era Moderna. O fim da Idade Média, período de forte centralização de poder e segregação da produção cultural, promove renovado vigor na circulação de conhecimento. "O entrelaçamento da literatura com o jornalismo, a ampliação dos domínios da escrita e o crescimento da produção de bens de consumo culturais 
franquearam o acesso ao conhecimento e à formação da esfera pública burguesa, que, aos poucos, foi se multiplicando e criando novos segmentos de especialização do trabalho intelectual" (LIMA, 2006, p.15-16).

O desenvolvimento das primeiras máquinas impressoras foi, assim, parte e parcela do crescimento da economia capitalista do fim da Idade Média e início da Europa Moderna (THOMPSON, 2002). A polarização de domínio entre Estados e Igreja sofre um abalo. O saber, o acesso aos documentos, o direito à pesquisa estiveram, até a invenção dos tipos móveis por Gutenberg, nas mãos da Igreja. As primeiras publicações começaram a multiplicar o número daqueles a quem era dado conhecer os textos reservados, secretos ou sagrados (MARCONDES FILHO, 2002). Se, por um lado, o conhecimento se espalha e quebra a unidade religiosa, sendo o protestantismo um símbolo dessa abertura, o desabrochar da imprensa no Ocidente é marcado por muito amadorismo e uma tendência perniciosa ao superlativo. As publicações se tornam periódicas e mudam a forma dos indivíduos se relacionarem com o mundo e as notícias, experiência esta, até então, pautada pela realidade presencial e relatos orais. Os problemas deixam de derivar apenas dos limites da experiência de cada um e das trocas interpessoais.

O surgimento da imprensa subverte a dicotomia entre público e privado. Antes do desenvolvimento da mídia, a publicidade das pessoas ou dos acontecimentos era ligada ao compartilhamento de um lugar comum (THOMPSON, 2002). O presencial deixa de ser protagonista; os eventos são documentados e passam a se corporificar no papel. O jornalismo impresso transfigura o ideal de espaço público e agrega um novo espaço de discussão, difusão e apropriação do que é domínio social. Como todas as formas de publicidade mediada, a forma criada pela palavra impressa foi separada da partilha de lugar comum: com o advento da imprensa, ações e eventos poderiam ser revestidos de publicidade na ausência de indivíduos co-presentes (THOMPSON, 2002). O público leitor forma uma coletividade de difícil classificação, mas plenamente atuante.

Se o século XVIII é marcado pelo uso sistêmico da informação e do saber como instrumento de empoderamento e controle, o início do século XIX marca uma saída da imprensa mais rústica para a escala industrial e inevitável expansão de conteúdo. Soma-se ao novo quadro europeu uma explosão demográfica surpreendente e maior acesso à leitura, nutrição para o crescimento da indústria jornalística.

O Primeiro Jornalismo, de 1789 à metade do século 19, foi, assim, o da "iluminação", tanto no sentido de exposição do obscurantismo à luz, quanto de esclarecimento político e ideológico. O controle do saber e da informação 
funcionava como forma de dominação, de manutenção da autoridade e do poder, assim como facilitava a submissão e a servidão. [...] Desmoronando esse poder, entra em colapso igualmente seu monopólio do segredo. A época burguesa inverte o processo: agora tudo deve ser exposto, superexposto, ostensivamente mostrado (MARCONDES FILHO, 2002, p.11).

Os incipientes conglomerados de informação passam a enxergar o público como consumidor. De jornais de leitura restrita, feitos para atender a uma certa fatia elitizada, temos neste momento uma busca por um público anteriormente desprovido de atenção, a ser conquistado, desejoso de inclusão e ávido por informação. À medida que a atividade gráfica foi se tornando mais industrializada e o mercado foi se expandindo, a sua base de financiamento começou a mudar. Enquanto os jornais dos séculos XVII e XVIII tinham como alvo principal um setor restrito da população mais afluente e instruída, a indústria de jornais dos séculos XIX e XX se dirigiu para um público cada vez mais vasto.

Os impressos passam a adotar um jornalismo informativo mais leve e atraente, visando alargar o círculo de leitores. Este novo momento do segmento econômico gráfico inclui a abolição dos impostos, que permite reduzir os preços, e a inclusão da propaganda na lógica comercial. Os periódicos estão mais acessíveis à população média e o modelo econômico começa a se consolidar. O tradicional editor-proprietário, que tinha um ou dois jornais de interesses familiares, gradualmente cedeu a vez para o desenvolvimento de organizações multimídia e multinacionais de grande porte (THOMPSON, 2002).

A ânsia por informar e derrubar todas as barreiras de tempo-espaço justifica-se à medida que os grupos midiáticos entendem com cada vez mais lucidez a importância de um mundo conectado. O valor da informação nos vínculos de poder presentes no espaço social é altíssimo, sendo a própria relação da comunidade com a autoridade reinterpretada. Para Marcondes Filho (2002), as décadas iniciais de 1800 já sofreriam as primeiras consequências sociais das revoluções burguesas. Lutas sociais, como o direito ao voto, dividem a esfera pública com partidos políticos nacionalistas, operários, liberais, num frenesi que culminaria no Segundo Jornalismo. É quando os donos das empresas de informação europeias percebem que a emoção não pode ser decisiva e o jornalismo pode ser um organizador e, ao mesmo tempo, muito lucrativo. É preciso pôr ordem na casa - chão este que se finca em tonalidades capitalistas.

O Segundo Jornalismo, o do jornal como grande empresa capitalista, surge a partir da inovação tecnológica da metade do século 19 nos processos de produção do jornal. A transformação tecnológica irá exigir da empresa jornalística a capacidade financeira de autossustentação, pesados pagamentos periódicos para amortizar a modernização de suas máquinas; irá transformar uma atividade praticamente livre de pensar e de fazer política em uma 
operação que precisará vender muito para se autofinanciar. A fase romântica em que o valor pedagógico era financiado pela falência do jornal (Habermas) cede passo à imprensa moderna e sintonizada com as exigências do capital (MARCONDES FILHO, 2002, p.13).

No roldão da nova matriz surge o folhetim francês, os feuilettons, jornais feitos para entreter os leitores com resenhas teatrais, dicas de culinária e comentários sobre a vida mundana, plataforma embrionária dos primeiros cronistas coetâneos. "Nasce então o folhetim, primeiro tipo de texto escrito no formato popular de massa. Fenômeno muito mais que literário, o folhetim conforma um espaço privilegiado para estudar a emergência não só de um meio de comunicação dirigido às massas, mas também de um novo modelo de comunicação entre as classes" (BARBERO, In: SOUZA, 2012, p.36). Os folhetins agradavam diversas classes sociais. Os principais escritores franceses da época, como Honoré de Balzac, Alexandre Dumas e Victor Hugo, publicavam suas histórias em edições anunciadas até em panfletos nas vias públicas. A família aguardava o jornal chegar em casa para se reunir, muitas vezes à noite, e ouvir as histórias pitorescas (SOUZA, 2012).

O folhetim-romance representava uma saída dos impressos do viés político e panfletário de sua gênese e uma chegada ao entretenimento e desejo de se tornar esfera importante da discussão pública. O jornalista e político francês Émile de Girardin, fundador do La Presse, é o primeiro publisher a trazer o formato para a periodicidade regular. "O folhetim vai ser completado com a rubrica 'variedade', que é por onde penetra a ficção, na forma de contos e novelas curtas. O passo decisivo é dado quando Girardin, utilizando o que já vinha sendo feito para os periódicos, decide publicar ficção em pedaços. Está criado o máximo chamariz “continua no próximo número"” (MEYER, 1996, p.23).

Alexandre Dumas, já reconhecido romancista e dramaturgo, é considerado o responsável pela popularização maciça do folhetim e definidor da estrutura técnica e linguística do novo gênero. Ele trouxe um acabamento que parecia talhado para o impresso ressuscitar a cada semana, seduzindo (ou enrolando) o leitor. Nadaf (2009) atenta para o fato de que o escritor ganhava por linha escrita, o que o levava a tornar a estória a mais longa possível.

Neste ínterim, a crônica, torna-se consanguínea ao folhetim, foge aos poucos do hiperbólico para se definir em algo mais sensato. Ela deixa a eloquência desmedida dos folhetinistas e firma-se numa outra camada. "O conceito de crônica como gênero literário inicia-se com o folhetim. O cronista literário deixa, assim, de ser o intérprete da visão das classes dominantes, para ser o porta-voz dos sentimentos do homem comum, fazendo da 
crônica o relato de fatos e episódios que a historiografia tradicional não registrava" (COUTINHO, 2006, p.45).

É uma casta em transfiguração, que começa a arrogar para si um território livre. O gênero se transforma naquele pedaço da imprensa onde se cultiva a sensação de que o mundo continua livre - como os pardais, as nuvens e os vagabundos (DIAFÉRIA, In: MELO, 2003). Para Souza (2012), a crônica se tornou uma linguagem textual em contato direto com o cotidiano e a banalidade da vida, revelando uma informação interpretativa que pode ter ou não valor noticioso, ou seja, comentários personalistas sem compromisso com a durabilidade, mas capazes de permanecer de acordo com a relevância e contemporaneidade do discurso. Amâncio, no prefácio de Cronistas do Estadão, de 1991, compilação das melhores crônicas publicadas em mais de cem anos do periódico, afirma ser batalha perdida encaixotar o gênero.

A crônica, oficialmente, não existe. Mas, como ocorre com bruxas, há sempre alguém disposto a testemunhar que já a viu - e nas mais diferentes formas. Pode aparecer na forma de comentário sobre a cena política, ou como recorte da infância. Ontem, disfarçou-se em digressões sobre o cotidiano. Amanhã, será poema em prosa. Às vezes, exibe-se como trecho de algum romance que vai consumindo o autor ao longo de muitas madrugadas. Assume ainda características de ensaio, ou de experimentação estilística. Pode ser brincalhona, amarga, profunda, superficial, atrevida. Tentativas de enquadrála com rigor em algum gênero não parecem recomendáveis (AMÂNCIO, 1991, p.9).

Fischer (2013, p.22) especula que o contorno atingido no País é resultante do sucesso de muitos escritores em uma prosa mais curta e incisiva, como se tivéssemos um outorgamento: "O Brasil é bom em gêneros artísticos breves: crônica, canção e caricatura, talvez também o conto. Nos gêneros mais longos temos coisa boa com o melhor que o mundo já produziu, como Machado de Assis e Guimarães Rosa, mas parece que nos breves a gente se dá bem de modo mais tranquilo".

Uma coisa é certa: o público não dispensa a crônica, e o cronista afirma-se cada vez mais como o cafezinho quente seguido de um bom cigarro, que tanto prazer dão depois que se come (MORAES, In: WERNECK, 2005). Segundo Fischer, a crônica nacional apodera-se de uma verve dialógica que universaliza o discurso. "Tem mesmo algo de particular na crônica brasileira, embora se possa encontrar gente escrevendo impressões pessoais em jornais e revistas do mundo afora. Talvez seja o fato de a crônica ter-se constituído, ao longo da história, num gênero afinado com a informalidade brasileira, ter acolhido a língua cotidiana" (FISCHER, 2013, p.22).

Luiz Beltrão (1980), por sua vez, afirma que a crônica passou por um processo de depuração sui generis até chegar ao seu formato atual, mesmo nutrindo-se de outros víveres 
estilísticos. Ela se descola da historicidade, assume seu elo literário e poder jornalístico, para ser fronteiriça: características que auxiliam na compreensão de suas idiossincrasias. "Em sua origem [a crônica] era um gênero histórico. Evoluindo, vestiu roupagem semântica diferente: englobou à narração o comentário; deixou de parte o rigor temporal (o que atua) e se define como forma de expressão do jornalista-escritor para transmitir ao leitor seu juízo sobre fatos, ideias e estados psicológicos pessoais e coletivos" (BELTRÃO, 1980, p.67).

Outro fator importante no juízo do gênero é a linha tênue entre o existente e o inventado, a natural ficcionalização das pessoas reais, uma quase revisitação do propósito poético de Fernando Pessoa: um fingidor a fingir a dor que deveras sente. Para Sato (2002), a possibilidade de o cronista inventar incidentes, contar histórias, traz para as páginas do jornal um fazer literário por excelência, que permite criar um outro real. A alteração do sentido supostamente natural e linear das coisas para uma conotação mais aberta é o que confere à crônica o seu império.

\footnotetext{
Dar abrigo a emoções e a fatos inventados ou recuperados pela memória parece ser a grande arma da crônica na captura do interesse do leitor, convidando-o para um tipo diferente de mergulho no real, mais ameno e prazeroso, quiçá mais profundo. Para o leitor, a crônica funcionaria como descanso, pois, a partir de um evento qualquer, em linguagem que tende para a ambiguidade, para a plurivocidade, o cronista tece um texto que pode atingir a categoria de ficção pura ou confrontar diferentes tempos para fazer uma construção metonímica da imagem do presente por meio de pequenos incidentes (SATO, 2002, p.34).
}

Muito do preconceito em relação aos cronistas advém do fato do primeiro time da ficção nacional ser habitué das redações de impressos do fim do século XIX e todo o século $\mathrm{XX}$, o que supostamente prejudica o íntimo criador. Outro tanto é oriundo do próprio espectro folhetinesco que, muitas vezes, se enlaçou ao sombreamento e ao embuste literário. "Aos poucos o 'folhetim' foi encurtando e ganhando certa gratuidade, certo ar de quem está escrevendo à toa, sem dar muita importância. Depois, entrou francamente pelo tom ligeiro e encolheu de tamanho, até chegar ao que é hoje" (CANDIDO, 1980, p.8).

No Brasil, por volta de 1870, a profissão do escritor começa a se desenvolver, mas os livros não garantiam retorno financeiro. Escritores que ascenderam das classes baixas e médias muitas vezes atuavam como funcionários públicos e encontravam na crônica uma renda extra. O processo de incorporação da crônica ao cotidiano urbano é lento, porém contínuo: o novo formato passa a integrar o foro íntimo social.

A dificuldade expressa de definir o que é a crônica não deve ser o tipo de dilema que gere maiores perturbações teóricas. Antonio Candido entende que é justamente nesta fuga por 
uma identidade sumária (talvez fugaz) que o gênero se expande e se ressignifica, apontando para um viés comunicativo capaz de levar o leitor para uma nova experiência de mundo.

A crônica não é um "gênero maior". Não se imagina uma literatura feita de grandes cronistas, que lhe dessem o brilho universal dos grandes romancistas, dramaturgos e poetas. Nem se pensaria em atribuir o Prêmio Nobel a um cronista, por melhor que fosse. Portanto, parece mesmo que a crônica é um gênero menor. "Graças a Deus", seria o caso de dizer, porque sendo assim ela fica mais perto de nós (CANDIDO, 1980, p.5).

Ao fluir no terra-a-terra e manejar profundezas, ela também demonstra seu caráter não-excludente, uma intersecção entre o mundo aplicado e o terreno da fruição, sem jamais deixar de ser testemunhal. Para o escritor Xico Sá (2013), a crônica é o prato feito da literatura brasileira, o arroz, feijão, bife e um ovo estrelado por cima, o gênero vira-lata por excelência. Exatamente por este desprendimento formal, a função de um cronista em um periódico é geralmente descompromissada e não segue as regras jornalísticas, sendo, assim, o responsável por quebrar a norma densa do jornal (SOUZA, 2012).

Não é possível afirmar, apesar do vigor, pujança e vasta territorialidade de nossos cronistas, que a crônica moderna, em todo o seu percurso histórico, tenha sido criada no Brasil. Para Shirts, é quase uma pretensão. "É exagero afirmar que a crônica tenha sido inventada no Brasil. A esse respeito, gosto de citar o escritor e estudioso Humberto Werneck. Foi ele quem resumiu a questão de forma definitiva. Diz ele que, tal como o futebol, a crônica não foi inventada no Brasil, mas aqui se aclimatou bem” (SHIRTS, In: CANDIDO, 2013, p.31).

Mais sensato ainda é pensar que a partir das décadas de 1930-1940 o gênero se eleva. Nossos escritores, de um modo geral, estão mais maduros e o movimento modernista atinge seu auge, absorvendo as transformações de um país que deixa seu passado rural, expõe mais abertamente suas relações e dificuldades afetivas. Escrevem numa língua que também amadureceu, está mais uniforme e representativa daquela usada no cotidiano pelos brasileiros educados, de qualquer lugar do país (MORICONI, 2000). E a transcendência na crônica tem um nome:

No decênio de 1930 que a crônica moderna se definiu e consolidou no Brasil, como gênero bem nosso, cultivado por um número crescente de escritores e jornalistas, com seus rotineiros e os seus mestres. Nos anos 30 se afirmaram Mário de Andrade, Manuel Bandeira, Carlos Drummond de Andrade, e apareceu aquele que de certo modo seria o cronista, voltado de maneira praticamente exclusiva para este gênero: Rubem Braga (CANDIDO, 1980, p.9). 
O ofício de produzir crônicas regularmente sempre lançou o escritor-jornalista diante de abismos técnicos - a celeridade e a interpretação do momento - e a dificuldade de permanecer enquanto discurso. Dentre os gêneros literários, a crônica é o mais ingrato. Servos do transitório, são raríssimos os cronistas que conseguem impregnar seus textos com elementos capazes de extrapolar o banal, conceder ao corriqueiro uma perspectiva inusitada (GURGEL, 2013). Elaborar uma nova percepção informativa a partir da matéria dos dias exige, sim, mérito artístico, faro e sensibilidade aprofundada. Em contrapartida, flerta-se com um risco iminente: o fracasso em duas frentes.

O desafio de procurar escrever bem, no caso do jornalismo, apresenta dois grandes perigos. A literatice é o primeiro. O jornalista esquece-se do leitor e da notícia, entra em delírio criativo, fica embevecido com seu texto e acaba fazendo literatura de má qualidade. [...] O segundo perigo é a invencionice. Há repórteres que, no afã de tornar a matéria mais interessante, acrescentam detalhes, produzem frases e carregam nas tintas de tal forma que a realidade acaba substituída pela ficção (MARTINS, 2005, p.113).

A aparência de simplicidade, portanto, não quer dizer desconhecimento das artimanhas artísticas (SÁ, 1985). A crônica integra-se umbilicalmente ao modo de produção jornalístico, irmanando-se, de certa forma, no que o impresso tem de mais precário: a tendência ao efêmero.

A crônica surge primeiro no jornal. [...] Nasce no começo de uma leitura e
morre antes que acabe o dia, no instante em que o leitor transforma as
páginas em papel de embrulho, ou guarda os recortes que mais lhe interessam
num arquivo pessoal. O jornal, portanto, nasce, envelhece e morre a cada 24
horas. Nesse contexto, a crônica também assume essa transitoriedade,
dirigindo-se inicialmente a leitores apressados, que leem nos pequenos
intervalos da luta diária, no transporte ou no raro momento de trégua que a
televisão lhes permite. Sua elaboração também se prende a essa urgência: o
cronista dispõe de pouco tempo para datilografar o seu texto, criando-o,
muitas vezes, na sala enfumaçada de uma redação (SÁ, 1985, p.10).

Ao evocar o humano e o simplório, é possível afirmar que a crônica recaracteriza o formato folhetinesco e estabelece uma via intercambial. À pressa de escrever, junta-se a de viver. Os acontecimentos são extremamente rápidos, e o cronista precisa de um ritmo ágil para poder acompanhá-los, por isso a sua sintaxe lembra alguma coisa desestruturada, solta, mais próxima da conversa entre dois amigos do que propriamente do texto escrito (SÁ, 1985).

Os riscos da insignificância e de ser desimportante são evidentes ao cronista. Entretanto, profissional de tempo escasso, é preciso até escrever sobre a falta de assunto para que seu trabalho ocorra diariamente.

Já que ele não dispõe da flexibilidade de tempo de um ficcionista escrevendo sem data certa para publicar o livro, o cronista, "se ele é cronista mesmo", se impõe o ato de escrever, determinando a si próprio "que ela seja bem feita e 
divirta os leitores". É sem dúvida em decorrência dessa imposição que certas crônicas envelhecem logo, enquanto outras se revelam duradouras, ultrapassando a efêmera página jornalística e chegando à durabilidade do livro (SÁ, 1985, p.75).

Na crônica contemporânea, o dialogismo serve como ferramenta de aproximação entre dois tradicionais opostos. Ele equilibra o coloquial e o literário, permitindo que o lado espontâneo e sensível permaneça como elemento provocador de outras visões do tema e subtemas que estão sendo tratadas numa determinada crônica, tal como acontece em nossas conversas diárias e em nossas reflexões, quando também conversamos com um interlocutor que nada mais é do que o nosso lado, outro lado, nossa outra metade, sempre numa determinada circunstância (SÁ, 1985). A crônica subverte, então, a definição clássica de comunicação midiática, da via de acesso exclusiva a quem produz o conteúdo.

No jornalismo impresso, o fluxo de comunicação é esmagadoramente no sentido único, mesmo considerando o espaço do leitor nas seções de cartas, a possibilidade de telefonar para a redação ou mesmo o retorno crítico de conteúdo - além da escolha evidente de simplesmente ignorar e não consumir o conteúdo. Ainda mais popular do que as notas de rodapé dos primeiros jornais europeus dos primórdios da Revolução Industrial, a crônica se transfigura num espaço ao mesmo tempo de fuga, encontro, interpretação e expansão.

Da crônica se poderia dizer o que disse Mário de Andrade a respeito do conto: é tudo aquilo que chamamos de crônica. Quase tudo, de fato, cabe nesse rótulo ecumênico, da pequena peça de ficção ao poema em prosa, passando pela reflexão acerca de miudezas do cotidiano. A própria falta de assunto, volta e meia, vira assunto. [...] Com seu agridoce bom humor, Rubem Braga, o maior dos cronistas brasileiros, respondeu certa vez a alguém que lhe pedira uma definição do gênero: "Quando não é aguda, é crônica" (WERNECK, 2005, p.7).

\section{O cronista Rubem Braga}

Braga é o nono de uma família de doze filhos. Sua família tem origens que remetem à cidade de Braga - herança da época migratória em que os portugueses batizavam-se no Brasil com o nome da cidade natal. Moraes localiza de forma bem direta a autoridade de Braga. "A ele devemos ter devolvido à crônica a condição de permanência como gênero literário. $\mathrm{O}$ que Rubem Braga escreve não é apenas um trabalho jornalístico, mas a criação de um escritor cujo tema é colhido na observação pessoal dos fatos da vida cotidiana e dos acontecimentos de nosso tempo" (MORAES, In: BRAGA, 1993, p.45). 
Torna-se um ícone entre o comentário, o posicionamento ideológico e as reminiscências da vida -, sem, em nenhum momento, separar o leitor do processo expressivo e negar o seu próprio sangue de jornalista interpretante. Segundo Sá, Braga devolve ao leitor sinais da existência que diariamente deixamos escapar, torna-se um porta-voz disposto a restabelecer aquilo que a realidade não-gratificante sufocou.

O lirismo no mundo de hoje não pode ser a simples expressão de uma dor-decotovelo, mas acima de tudo um repensar constante pelas vias da emoção aliada à razão. Esse papel se resume no que chamamos de lirismo reflexivo. [...] Corajosamente, ele só tem publicado crônicas, mesmo que em uma delas confesse ter escrito um soneto "para enfrentar o tédio dos espelhos". Certamente capaz de escrever contos, novelas e romances, não se deixou seduzir pelo brilho dos chamados "gêneros nobres". Sua opção é ainda mais corajosa porque, vivendo num país de frases bombásticas, ele cumpre a principal característica do escritor: o despojamento verbal, que implica uma construção ágil, direta, sem adjetivações (SÁ, 1985, p.13).

O valor literário do escritor da cidade mais secreta do mundo - modo carinhoso como se referia à sua cidade natal, Cachoeiro do Itapemirim - suplanta as divisões teóricas fragmentárias por alcançar um nível profundo de investigação da alma humana e de suas implicações. Enxugando a língua portuguesa de academicismos em prol da maior expansão comunicativa - sem, para isso, reduzi-la de sentido -, Braga trouxe à crônica um viés literário singular e um rigor de profissional assíduo das principais redações nacionais, atingindo no seu espaço cativo e limitado uma amplitude imensurável.

Analisar os desdobramentos históricos e o olhar autoral e comovente da obra braguiana é também entender de um modo menos pragmático os principais acontecimentos históricos do período em que atuou e o seu impacto na contemporaneidade.

Foram mais de sessenta anos de textos, que traçam um painel da vida brasileira, ao longo de um tempo que vai do governo Getúlio Vargas até 1990. [...] Trata-se de um momento histórico de notáveis acontecimentos no país: entre muitos, alternâncias de ditaduras e regimes democráticos, Segunda Guerra Mundial, condições subdesenvolvidas e dimensões de primeiro mundo, convívio com os avanços científicos e tecnológicos avassaladores deste atribulado século em que vivemos, participação nos meios de comunicação de massa, com sua atuação acentuada no comportamento dos indivíduos, mudanças de valores e comportamento nas relações afetivas (PROENÇA FILHO, In: BRAGA, 1997, p.9).

Detentor de uma disciplina exemplar, considerava-se uma máquina de escrever com algum uso, mas em bom estado de funcionamento, conforme confidenciou certa vez ao amigo Fernando Sabino: "Sempre escrevi para ser publicado no dia seguinte. Como o marido que tem que dormir com a esposa: pode estar achando gostoso, mas é uma obrigação" (BRAGA, In: WERNECK, 2005). 
Escritor de um tempo em que o impresso dominava, ao lado do rádio, a circulação da informação; e depois contemporâneo da televisão, Braga não pôde acompanhar a crise jornalística dos anos zero do século XXI e a diminuição gradual e firme da crônica nos “jornalões”, um modelo econômico, por sinal, assolado por uma crise existencial duradoura, a fechar tradicionais marcas pelo mundo.

Sá pergunta - e responde -, diante da preocupação básica do jornal com a notícia, com o fato em si (deixando em segundo plano as pessoas que participaram da cena), qual a função da crônica no espaço jornalístico:

\begin{abstract}
Aberta a janela, cumpre ensinar o leitor a ver mais longe, muito além do factual. Isto só é possível quando o fato, os personagens e a preocupação estética revelada na estruturação do texto se associam para que o resultado final alcance a empatia com o leitor. Uma empatia que significa a cumplicidade entre quem escreve e quem lê, mas também a elaboração de uma linguagem que traduza, para o leitor, as muitas linguagens cifradas do mundo. Portanto, a função da crônica é aprofundar a notícia e deflagrar uma profunda visão das relações entre o fato e as pessoas, entre cada um de nós e o mundo em que vivemos e morremos, tornando a existência mais gratificante. [...] Logo, o jornal nos dá notícias da vida e da morte; a crônica nos faz compreender a coexistência desses dois elementos que se opõem, mas não se excluem (SÁ, 1985, p.56).
\end{abstract}

A tendência à segmentação da informação jornalística na contemporaneidade naturalmente retirou muitos cronistas do mercado, historicamente impróprio à vivência exclusiva dentro do gênero, e impediu a renovação dos autores nas páginas dos grandes jornais impressos, cada vez mais pressionados pelos custos, dificuldades para fechar suas contas de modo satisfatório e pela própria crise existencial no modelo de negócio.

\title{
Rubem Braga: Político
}

A reunião periódica de conteúdo de jornal em livro sempre foi, em Braga, antes de tudo, uma reavaliação própria dos méritos de sua escrita, aquilo que o autor considerou capaz de resistir às intempéries do tempo. Na primeira edição de $O$ Conde e o Passarinho, seu livro de estreia, chama a atenção o seu prefácio minucioso e preciso, escrito em 31 de dezembro de 1935, revelando sua genealogia jornalística e, à margem, a sua preocupação com a permanência literária.

Já escrevi umas duas mil crônicas. É natural, eu vivo disso. Estas aqui não são as melhores; podem dizer que escolhi mal, tanto do ponto de vista literário como do ponto de vista revolucionário. Mas estas representam as outras. Quero dizer que elas também representam a mim. Falam de minhas forças e de minhas fraquezas. Aqui encontrarei os queixumes e os palpites de um jovem jornalista pequeno-burguês de um país semicolonial. Também encontrarei um e outro sorriso. Mas não muito alegres. Sempre tive maus 
dentes e não conheço, por isso, riso rasgado, fácil e feliz. Sou jornalista, o que quer dizer: nem um literato nem um homem de ação. Escolhi eu mesmo a minha profissão; não me queixo. Mas ao leitor de livros quero avisar que não escrevi este livro para ele. Tudo que está aqui foi escrito na mesa de redação, entre um telegrama a traduzir e uma reportagem a fazer. Raramente na minha vida escrevi algo que não fosse para o dia seguinte (BRAGA, 1936, p. 3).

As coletâneas e as antologias comprovam o poder de Braga como escritor, o vigor de seu discurso e a força de sua obra. São materiais fundamentais para a compreensão histórica e social do País; muitos textos, inclusive, possuem evidente valor jornalístico por apresentarem informações e comentários que lançam maior luminosidade a determinados fatos relevantes. Em um cronista, a necessidade de engajar-se é menos considerável, mas ele é também afetado pela corrente dos acontecimentos e dos (des)caminhos midiáticos. Ele pode, diante dos grandes eventos, optar por narrar o que considera importante na balança de seus valores profundos ou mesmo abdicar de se posicionar abertamente, como se desatrelado do real, numa espécie de mise-en-scène.

Em Braga o viés político, apesar de, ao longo de sua trajetória, se tornar cada vez menos ruidoso, sempre foi uma marca constante - e se os jornais em que trabalhou estavam lá a cobrir os rumos do País, ele esteve presente de seu modo. Podemos subdividir seu campo de observação em textos em que ele está efetivamente vinculado aos fatos, como jornalista em cobertura, um analista da história em movimento, e crônicas em que ele transpassa os eventos, lançando seu olhar singular diante do que vê, como um narrador benjaminiano histórico.

A crônica A Revolução de 30 é um exemplo de como o olhar pessoal avança ao encontro do fato jornalístico, esfarelando as trincheiras entre subjetividade e objetividade. Ele entrega ao leitor aquilo que Coutinho (2004) classifica como crônica-informação, mais próxima do sentido etimológico, aquela que divulga fatos, tecendo sobre eles comentários ligeiros. É o autor imiscuindo-se à realidade.

1929-30 foi uma das fases mais dolorosas da minha vida. [...] Em outubro de 1930 eu devia estar em Cachoeiro, pois as aulas da faculdade estavam suspensas; fiquei no Rio para me tratar. No dia 24 de outubro vim ao médico, na Rua José. Quando saí do consultório, notei um movimento na Galeria Cruzeiro. Fui para lá: todo mundo dizia que a Revolução tinha vencido. Custei a acreditar, inclusive porque eu era contra a Aliança Liberal. Um conhecido me convidou para ir até o Palácio Guanabara, onde diziam que o presidente já estava cercado. Preferi ficar vagando pela avenida, que logo se encheu de povo; passavam automóveis abertos com gente de lenço vermelho a dar gritos de viva e morra; não me esquecerei de uma mulher meio gorda, de pernas abertas, sentada no radiador (BRAGA, 1986, p.65).

Erbolato (2011) encontra uma certa uniformidade naquilo que os jornalistas buscam entregar ao leitor. Na sua escala de notícias, a crônica acima pode ser enquadrada no quesito 
proximidade. Para ele, a grande arma dos jornais do interior e dos semanários comunitários é a divulgação dos fatos que ocorrem perto do leitor e a ele ligados. Considerando Braga como um sujeito interpretante, ele recoloca o leitor no eixo de acontecimentos em suas adjacências, sem, de forma alguma, abdicar de participar da teia narrativa.

A Revolução de 30 foi a precipitação de diversos implicâncias sociais e econômicas do País. Durante os quase 40 anos de uma recém-instaurada República, muitos presidentes enfrentaram rebeliões e tentativas de golpe. De modo geral, os setores oligárquicos, especialmente concentrados em São Paulo e Minas Gerais, exerciam enorme pressão sobre os governos, centralizavam o poder e auxiliaram na criação de um clima de insatisfação popular. O Crash da Bolsa de 1929 e a derrocada da elite cafeeira são o estopim da Revolução.

Ainda em início de carreira, Braga não tem papel fundamental no que tange à sua atuação jornalística no período. Entretanto, seu percurso memorioso é útil e informativo por entregar ao leitor uma atmosfera psicologizante do evento e vermos como ele se mantém, ao mesmo tempo, internalizado no fato e distante a ponto de oferecer um painel histórico.

\begin{abstract}
Depois de muito vagar, encontrei Leonardo Mota, que passara uma temporada em Cachoeiro. Ele também, se não era contra, não dava mostras de simpatizar com aquela revolução; ficamos a vagar pelo meio da avenida, calados e sérios, no meio da multidão exaltada. Assistimos juntos ao incêndio de O País. Vimos a chegada dos bombeiros, e a gente do povo subindo em seus carros para impedir que eles trabalhassem. Cada sujeito que saía da redação já em chamas trazia alguma coisa de lá; vi muitos que traziam um exemplar de um dicionário português ilustrado de capa vermelha, creio que Séguier. Fomos depois até o Monroe; um colega meu de faculdade, que era "liberal" exaltado, fazia discurso trepado em um daqueles leões; todo o mundo parecia ter prazer em pisar na grama, como se isso fosse o símbolo de todas as liberdades de que o povo iria gozar. Havia uma alegria mais forte do que os gritos de ódio que alguns davam - "matar Romeiro Zander!", me propunha insistentemente, não sei por quê, um sujeito - uma alegria de que eu não participava, mas que olhava com calma, com uma certa melancolia, como achando que o meu povo tinha ficado doido (BRAGA, 1986, p.65).
\end{abstract}

O período entre 1930-1945 é marcante na trajetória intelectual de Braga, tanto por ser época de intensa agitação política, como por se tratar do ápice do engajamento do autor nas questões sociais, inclusive na política partidária. Em setembro de 1935, por exemplo, Braga está trabalhando no Rio de Janeiro, onde escreve para A Manhã. A sede do jornal é empastelada depois do fracasso da Intentona Comunista, organizada pelo Partido Comunista Brasileiro, e Braga fica desempregado. Em 10 de novembro de 1937 é decretado o Estado Novo, que duraria até 1945. O Congresso é fechado, iniciando uma turnê de muitas prisões e perseguição política. Durante a vigência do governo Vargas mais de 420 jornais não obtiveram registro e 61 foram obrigados a suspender sua circulação (TRAVANCAS, 1992). 
Morando no Rio de Janeiro, em 1938, Braga escreve para O Imparcial e, juntamente com Samuel Weiner e Azevedo Amaral, funda a revista Diretrizes, um marco do jornalismo nacional. Neste mesmo ano, perseguido pelo regime de Vargas, refugia-se no sítio de Carlos Lacerda, de quem é amigo íntimo. Ao longo de sua carreira, em diversos momentos Braga se posiciona geralmente contra os desmandos políticos, o cerceamento da liberdade e a injustiça social, acumulando, assim, inúmeras contendas públicas. E prisões. Em certas crônicas, mais comuns em seu universo crítico, como Recenseamento, de 1934, encontramos um autor mordaz, carregado em entrelinhas, uma voz sempre a fazer a opção por ser gauche na vida. "São Paulo vai se recensear. O governo quer saber quantas pessoas governa. A indagação atingirá a fauna e a flora domesticadas. Bois, mulheres e algodoeiros serão reduzidos a números e invertidos em estatísticas" (BRAGA, 2002, p.40).

Erbolato (2011) aponta para o interesse humano envolto às notícias. A frialdade das estatísticas, a descrição de uma obra pública que será inaugurada, bem como o discurso de um governador ou um debate na ONU, devem ser entremeados com notícias que falem do próprio homem que participa desses acontecimentos. Aos olhos do cronista, como pudemos ver acima, há o fato estreito - um recenseamento -, há a vida que corre e se estanca no papel - a notícia de jornal -, mas cada indivíduo segue indivisível, largo, desmatemático: animal político sem uniformidade.

\section{Rubem Braga: Correspondente de guerra}

O narrador benjaminiano tradicional é, antes de tudo, um contador de estórias, antimecanicista. A Revolução Industrial e a busca incessante por racionalidade - e padronização - trouxeram ao jornalismo do século XX uma certa fé metafísica na racionalidade, obscurecendo o papel original do jornalista na genealogia dos encantadores através da oralidade e da palavra. Tuchman (In: TRAQUINA, 2005) alerta-nos para o fato de a notícia, como todos os documentos públicos, ser uma realidade construída possuidora da sua própria validade interna, não sendo possível abstrair a individualidade do processo de entrega informativa.

Trazendo o parâmetro da impossibilidade de "contaminação" personalista da notícia para o universo do cronista, podemos enxergar este último como uma espécie de bricoleur, um self-made man, um personagem de si, com raio de ação e prisma sem definição estática, tanto no espaço-tempo - embora não seja possível desconsiderar sua necessária obediência aos prazos de redação -, quanto na linguagem. 
A cobertura de guerra entranhou-se em Rubem Braga, mesmo quando ele não estava diretamente em campo de batalha. Um caso elucidativo de seu espírito intempestivo está relacionado ao começo da Segunda Guerra Mundial. Em 1939, Braga entrevista pela Folha da Tarde, de Porto Alegre, um membro da colônia polonesa gaúcha que afirma estar feliz por ter sido dada à Polônia a oportunidade de acabar com a Alemanha e a Rússia juntas. A matéria repercute mal. Ele é preso em Porto Alegre, acumulando sua terceira detenção em menos de dez anos, e mandado de navio para Santos. Mas, com receio de ser novamente detido no desembarque, foge quando o navio ancora em Paranaguá, seguindo para São Paulo de carro. Na capital, passa a escrever para $O$ Estado de S.Paulo.

Em 1944, o Brasil entra de vez na Guerra e se coloca em posição de enviar suas tropas para combater os nazistas na Itália. Entre fevereiro de 1944 e junho de 1945 Braga mantém uma coluna no Diário Carioca chamada Ordem do Dia, dedicada aos desdobramentos do conflito. Sua estreia evidencia o tom de narrador pessoal e intimista que adotará em todo o percurso, com um certo tom irônico.

Tenho olhos, vejo as coisas. Leio as notícias; e tenho mão, e conto e escrevo, e depois sai no jornal. Falarei bem dos amigos, mal dos inimigos, sem dar muito na vista. Não é também um juiz este aqui, a julgar homens e coisas; apenas um sujeito que fala disso e daquilo e de si mesmo (BRAGA, coluna "Ordem do Dia". Diário Carioca. 15 de fevereiro de 1944, p.3).

Posteriormente, é designado para cobrir in loco as atividades da Força Expedicionária Brasileira (FEB). Ele não conseguiu embarcar no primeiro escalão, em junho, formado somente com soldados, repórteres e cinegrafistas oficiais, mas integrou o segundo escalão, formado por 5.074 soldados, que partiu em 22 de setembro de 1944. É neste ínterim que Braga, aos 31 anos, assume de vez uma nova faceta, fundamental na compreensão de sua trajetória profissional e intelectual: o correspondente de guerra, aquela natureza de profissional sempre à beira do abismo. Ribeiro, correspondente na Guerra do Vietnã, afirma que assumir condições de risco no exercício de sua função permite uma leitura mais profunda sobre o caráter do jornalista.

O que leva um jornalista a uma cobertura de guerra ou a uma situação de perigo, um pouco é vaidade; um pouco é espírito de aventura; um pouco é ambição profissional; e muito, mas muito mesmo, é a sensação, entre romântica e missioneira, de que faz parte de sua vocação estar onde a notícia estiver, seja para ali atuar como testemunha da história, seja para denunciar o que estiver havendo de abuso de poder (político, psicológico, econômico, militar), seja para açoitar a injustiça, a iniquidade e o preconceito. Após tudo isso, uma pitada de falta de juízo (RIBEIRO, 2005, p.103). 
A partir de setembro de 1944, Braga enviou relatos do front, de acordo com as exigências de seu periódico. Dentro desta dinâmica, podemos entender que o cronista seguiu a lógica do imediatismo e o fator tempo, a condicionar todo o processo de produção das notícias, já que o jornalismo é marcado por horas de fechamento (WEAVER, In: TRAQUINA, 2005). Ele integrou-se, em sua cobertura de guerra de forte cunho jornalístico, a um processo de sabedoria narrativa. No fim da guerra, em 1945, Braga volta ao Brasil e lança Com a FEB na Itália, seu terceiro livro, coletânea de 83 colunas enviadas do front ao jornal fluminense e de mais algumas crônicas censuradas pelo Departamento de Imprensa e Propaganda.

O impacto jornalístico de seu trabalho, minucioso, rigoroso, sem jamais eclipsar o lado humano, pode ser entendido ao tratarmos de um texto sensitivo que foge do jornalismo duro de círio pascal. A menina Silvana, relato pungente da criança de dez anos atingida por estilhaços de granada, levada até a enfermaria onde o repórter ouvia médicos - e estes se debruçavam sobre o corpo da menina para retirar pedaços de aço -, é certamente uma das crônicas mais representativas do período.

\begin{abstract}
Um camponês velho deu as informações ao sargento: Silvana Martinelli, 10 anos de idade. A menina estava quase inteiramente nua, porque cinco ou seis estilhaços, de uma granada alemã a haviam atingido em várias partes do corpo. Os médicos e os enfermeiros, acostumados a cuidar rudes corpos de homens, inclinavam-se sob a lâmpada para extrair os pedaços de aço que haviam dilacerado aquele corpo branco e delicado como um lírio - agora marcado de sangue. A cabeça de Silvana descansava de lado, entre cobertores. [...] Ela me olhou quietamente. A dor contraía-lhe, num pequeno tremor, as pálpebras, como se a luz lhe ferisse um pouco os olhos. Ajeitei-lhe a manta sobre a cabeça, protegendo-a da luz, e ela voltou a me olhar daquele jeito quieto e firme de menina correta (BRAGA, 2001, p.55).
\end{abstract}

Em A menina Silvana, ele se utiliza de seu testemunho para abordar o sofrimento de uma criança, alheia às motivações do caos, mas inerente à destruição. O real é apenas um vago referente, reacontecendo com mais riqueza no enunciado do jornalista (MOTTA, In: MOREIRA, 2006). O seu relato está atrelado ao dia, é um valor-notícia. Para Kunczik (In: MOREIRA, 2006), valores-notícia são as suposições intuitivas com relação àquilo que interessa a um público determinado, àquilo que chama sua atenção. Em suas crônicas de guerra, ele foge do escândalo, do jornalismo amarelo, e afirma sua visão autoral de mundo em um contexto de caos e indignidade humana. Temos aqui um espírito cívico emitindo juízo de valor sob a vigência do presente. Ele opta por um referimento realista, transferindo ao leitor o peso das palavras. Não vemos um autor engajado no convencimento ideológico direto, embora, com o decorrer do texto, a margem se estreite. 
[..] Há 13 anos trabalho neste ramo - e muitas vezes não conto. Mas conto a história sem enredo dessa menina ferida. Não sei que fim levou e se morreu ou está viva, mas vejo seu fino corpo branco e seus olhos esverdeados e quietos. Não me interessa que tenha sido inimigo o canhão que a feriu. $\mathrm{Na}$ guerra, de lado a lado, é impossível, até um certo ponto, evitar essas coisas. Mas penso nos homens que começaram esta guerra e nos que permitiram que eles começassem. [...] É preciso acabar com isso, e isso só se acaba a ferro e fogo, com esforço e sacrifícios de todos, e quem pode mais deve fazer muito mais, e não cobrar o sacrifício do pobre e se enfeitar com as glórias fáceis. É preciso, acabar com isso, e acabar com os homens que começaram isso e com tudo o que causa isso - o sistema idiota e bárbaro de vida social onde um grupo de privilegiados começa a matar quando não tem outro meio de roubar (BRAGA, 2001, p.55-56).

Podemos observar acima como o autor ultrapassa a notícia de uma guerra que se espalha por toda a Europa e traz para próximo do leitor um drama específico. Logo em seguida, ele parte para uma elucubração ampla sobre o ser humano. As crônicas de guerra de Braga imanam-se facilmente em polos aparentemente opostos, como retrato de evento amplo e, ao mesmo tempo, personalização da guerra - o que demonstra um talento ímpar do autor no manuseio dos elementos. O Braga correspondente de guerra oferta as descrições de um narrador que relata os acontecimentos em que participa, um observador que não se esconde diante da imensidão dos fatos. Tudo oferece sentido, senão nada tem sentido (LÉVISTRAUSS, in TRAVANCAS, 1992). Ele carrega o leitor para pisar o chão italiano da guerra, entender as estratégias de ataque e conferir os personagens fundamentais da campanha da FEB.

[Braga] Não assume, entretanto, e felizmente, a isenção exigida pela natureza da missão jornalística. A emoção insiste em ceder lugar à descrição-narração objetiva, mas não consegue ausentar-se de todo. A fidelidade aos fatos emerge acrescida do destaque à dimensão humana dos soldados. Mesmo do inimigo (PROENÇA FILHO, In: BRAGA, 2002, p. 11).

É, antes de tudo, um significador: renomeia ruas, estradas e países com o seu olhar. Vê e avança para completar seu próprio percurso sensitivo, sem jamais esquecer seu príncipio básico de informar, como um diarista de bordo. A abertura da crônica Ataque a Montese, por exemplo, evidencia claramente suas intenções estéticas.

17 de abril, 1945. Depois de permanecer lânguida uma temporada, ao sol da primavera, a frente brasileira finalmente se animou. Os três últimos dias foram de combates rudes, e a batalha contínua. Os brasileiros estão mais uma vez tentando galgar elevações onde um inimigo bem fortificado e experiente resiste com tenacidade. O troar da artilharia, às vezes ensurdecedor, e o cacarejar metálico das metralhadoras ecoam pelas quebradas. Desses três dias de combate, o mais frutífero foi o primeiro - dia 14 - e o mais pesado foi certamente o segundo, dia 15 . No momento em que escrevo, a crista que fecha o horizonte ao norte de nossas posições continua em poder dos nazistas (BRAGA, 2002, p.71-72). 
Temos aqui um autor em pleno registro taquigráfico da história, presente em corpo em um momento crucial da guerra, entregando ao leitor imediato as condições gerais, mas, nem por isso, abdicando de sua veia observadora e manejo característico da palavra.

\section{Considerações finais}

O Velho Braga, como se autointitulava ainda moço (WERNECK, 2005), morreu numa quarta-feira, 19 de dezembro de 1990, num quarto do Hospital Samaritano, no Rio, às 23h30, vítima de uma parada respiratória consequente de um tumor cancerígeno na laringe que ele preferiu não operar, nem tratar medicinalmente. Na crônica Berço de Mata-Borrão, de As boas coisas da vida, última obra a ser publicada em vida e com edição supervisionada pelo autor, Braga relata a sua experiência de se informar sobre um novo cemitério.

\footnotetext{
Liguei. O homem lá disse que o serviço, com a urna, ficaria em 45 mil cruzados. Não, não aceitavam Cartão Nacional nem da Golden Cross. Na verdade há muitos anos escrevi uma crônica dizendo que queria ser cremado, e que minhas cinzas fossem jogadas discretamente da Ponte Municipal de Cachoeiro, no rio Itapemirim, já tão poluído que isso não o alteraria muito. Mas aí apareceu aquele filme La nave va, de Fellini, e minha ideia se tornou um tanto ridícula, como a da cantora lírica que desejava ter suas cinzas jogadas em alguma parte do Adriático. Esqueci de contar que o sujeito da Santa Casa perguntou-me se o corpo já estava preparado para o funeral. Acanhado, eu não lhe disse que ainda me faltava morrer (BRAGA, 2010, p.171).
}

Rubem Braga foi um poeta que calhou de exercer-se como cronista, intrinsecamente identitário da tribo jornalística. A veia lírica de sua obra é pungente. Para Coutinho (2004), é o mais subjetivo dos cronistas brasileiros e o mais lírico. Muitas de suas crônicas são poemas em prosa, apresentando a originalidade de uma imaginação poética. Ele foi certamente um grande escritor e sua importância histórica é inegável à literatura brasileira e à crônica moderna. Sua contribuição ao jornalismo contemporâneo do século XX é segura, valiosa, e o seu potencial dialógico de aproximar dois aparentes extremos - jornalismo e literatura -, de uma forma a confundir as fronteiras e gerar significados mais amplos, eleva-o ao cânone das letras nacionais. Interessante notar como Braga consegue inserir seu espelho diário contra a maré do cotidiano dos jornais. Ele tem histórias para contar de seu modo, subvertendo a lógica racionalista. A sua sempre nova partida ao papel é livre das amarras do fluxo de notícias, mesmo ele não deixando de estar imerso à panóplia geral.

É imprescindível reconhecer a contribuição que Braga trouxe principalmente à cobertura de guerra e aos desdobramentos políticos dos anos 1930-1945, época de intensas 
reviravoltas e dificuldades ainda atuais de leitura e compreensão. Seus relatos sobre a campanha da FEB na Itália têm grande valor histórico e são janelas clarificadas para a compreensão de um tempo confuso e de suas motivações. Pudemos enxergar um autor que sempre se posicionou, vigoroso, nunca um adorador de imagens.

Sorvidas sob a badalada do primeiro pão do dia e depois compiladas em tomos com evidente caráter de permanência, as crônicas de Braga são fundamentais na compreensão de seu tempo, atravessam gerações sem envelhecer, sem gastar-se, e podem ser analisadas por diversos ângulos, como este artigo demonstrou - um autor/poeta capaz de narrar jornalisticamente, com beleza e intensidade. Seu legado é enorme: um autor com fortes raízes informativas, um animal exótico de redação, a se infiltrar nas entranhas dos fatos, investigar a alma humana e relatar o encanto presente no banal e corriqueiro.

\section{Referências}

AMÂNCIO, Moacir. Cronistas do Estadão. São Paulo: Editora Ex-Libris, 1991.

BELTRÃO, Luiz. Jornalismo Opinativo. Porto Alegre: Sulina, 1980.

BENJAMIN, Walter. Os pensadores. São Paulo: Editora Abril Cultural, 1975.

BRAGA, Rubem. 200 crônicas escolhidas. Rio de Janeiro: Record, 34ª edição, 2011. . As boas coisas da vida. Rio de Janeiro: Record, 9a edição, 2010. . A traição das elegantes. Rio de Janeiro: Record, $7^{\mathrm{a}}$ edição, 2008. . Aventuras. Rio de Janeiro: Record, 2001. Carta a El Rey D. Manoel. Rio de Janeiro: Record, 1981. O verão e as mulheres. Rio de Janeiro: Record, 1986. Um cartão de Paris. Rio de Janeiro: Record, 1997.

CÂNDIDO, Antônio. A Vida ao Rés-do-chão. In: Para Gostar de Ler: Crônicas. SP: Ed Ática, 1980.

COUTINHO, Eduardo F. A crônica de Rubem Braga: os trópicos em palimpsesto. Revista Signótica, V.18, № 1, janeiro/junho, 2006.

COUTINHO, Afrânio. A literatura no Brasil. São Paulo: Global Editora, 2004.

DIÁRIO CARIOCA. Coluna Ordem do Dia, 15 de fevereiro de 1944, p.3

ERBOLATO, Mário. Técnicas de codificação em jornalismo. SP: Atlas, 2001.

FISCHER, Luís Augusto. Inteligência com dor. SP: Arquipélago Editorial, 2012.

GURGEL, Rodrigo. Perfumaria bilaquiana. Rascunho. Curitiba, ed. 154, fevereiro, 2013. 
LIMA, Marcelo. Jornalismo e literatura na modernidade. In: BARREIROS, Tomás; CASTRO, Alexandre; LIMA, Marcelo (orgs.). Jornalismo - Reflexões, experiências, ensino. Curitiba: Pós-Escrito, 2006.

MARCONDES FILHO, Ciro. A Saga dos cães perdidos. SP: Hacker Ed, 2002.

MARTINS, Franklin. Jornalismo Político. São Paulo: Editora Contexto, 2005.

MELO, José Marques de. Jornalismo Opinativo. SP: Ed Mantiqueira, 3ª Ed, 2003.

MEYER, Marlise. Folhetim. São Paulo: Companhia das Letras, 1996.

MOREIRA, Fabiane Barbosa. Os valores-notícia no jornalismo impresso: análise das ‘características substantivas' das notícias nos jornais Folha de São Paulo, Estado de São Paulo e o Globo. Porto Alegre, 2006.

MORICONI, Italo(org.). Os cem melhores contos brasileiros do século. RJ: Objetiva, 2000.

NADAF, Yasmin Jamil. O romance-folhetim francês no Brasil: um percurso histórico. Revista Letras, Santa Maria, v. 19, nº 2, julho/dezembro, 2009.

RIBEIRO, José Hamilton. O gosto da guerra. São Paulo: Objetiva, 2005.

SÁ, Jorge de. A Crônica. São Paulo: Ática, 1985.

SÁ, Xico, in JORNAL RASCUNHO, março de 2013, n 155 , Curitiba.

SHIRTS, Matthew, In: JORNAL CÂNDIDO, fevereiro de 2013, nº 19, Curitiba.

SOUZA, Ana Maria de. No doce das crônicas de Rubem Braga, o testemunho de um narrador de alguns fatos de 1964 a 1967, nas páginas da Revista Manchete. SP: 2012.

THOMPSON, John B. A Mídia e a Modernidade. Petrópolis: Vozes, 2002.

TRAQUINA, Nelson. Teorias do Jornalismo. Florianópolis: Insular, 2005.

TRAVANCAS, Isabel. O mundo dos jornalistas. São Paulo: Summus, 1993.

WERNECK, Humberto. Boa Companhia: Crônicas. São Pauo: Cia das Letras, 2005. 